Scientific article

Volumen 32(1):77-92. Enero-abril, 2021

e-ISSN 2215-3608, doi:10.15517/am.v32i1.41348

https://www.revistas.ucr.ac.cr/index.php/agromeso

\title{
Sensory dimensions of peach-palm fruit (Bactris gasipaes) and implications for future genetics ${ }^{1}$
}

\section{Dimensiones sensoriales del chontaduro (Bactris gasipaes) e implicaciones para su futura investigación genética}

\author{
Jose Maria Martinez $z^{2}$ Leidy Paola Moreno-Caicedo², Oscar Alfonso Loaiza-Loaiza ${ }^{3}$
}

1 Reception: May $13^{\text {th }}, 2020$. Acceptance: September $8^{\text {th }}, 2020$. This research was supported by the Colombian Corporation of Agricultural Research (AGROSAVIA, Corporación Colombiana de Investigación Agropecuaria) and was financed by the Colombian Agricultural Institute (ICA, Instituto Colombiano Agropecuario) through the technical and scientific cooperation agreement CN-009-2016 for management, maintenance, and conservation of the National Germplasm Banks.

2 Colombian Corporation of Agricultural Research (AGROSAVIA), Palmira Research Center. Diagonal a la intersección de la Carrera 36A con Calle 23, Palmira, Valle del Cauca, Colombia.jmmartinezr@agrosavia.co (corresponding author; https://orcid.org/0000-0003-4464-2374), lpmoreno@agrosavia.co (https://orcid.org/0000-0001-6225-0484).

3 Colombian Corporation of Agricultural Research (AGROSAVIA), La Selva Research Center. Km. 7, vía Rionegro - Las Palmas, Sector Llanogrande, Rionegro, Antioquia. oloaiza@agrosavia.co (https://orcid.org/0000-0002-4788-8129).

\begin{abstract}
Introduction. Long-term genetic improvement efforts in Latin America aimed to ameliorate peach-palm fruit farmers' technical capacities and livelihoods have proven to be ineffective. Although experts agree this is partly the result of large uncertainty regarding consumer preferences, such research remains as virtually nonexistent. Objective. To identify chemical and morphologic attributes that are attractive for final consumers of peach-palm fruit and how these attributes are related to final perceptions of fruit quality, through statistical and econometric methods. Materials and methods. By using the harvest from a large set of varieties from a peach-palm (Bactris gasipaes) germplasm bank in Southwestern Colombia, 482 evaluations were made between April to October of 2016 by local consumers who tasted the fruits and gave a report on their perception of taste/quality in a case study scheme. Combining these data with further information on fruit color, oiliness perception, and additional controls, an ordered logit regression model was set to identify the attributes that describe peach-palm fruits with the most favorable scores for their taste/quality perception. Results. Preferences on oil contents were not linear. Fruits perceived as high-oil were between 9 and $13 \%$ more likely to be considered as having the best taste/quality, while those perceived high-starch content were correlated with a significant aversion towards the fruit, namely $43 \%$ less likely to be among the best fruits. Conclusion. A great deal of research is yet to be done around peach-palm fruit consumer preferences and, furthermore, it should be carried on an interdisciplinary ground. Further analyses of desired fruit traits should be made at sub-national levels, identifying ranges of suitable oiliness and morphological expected attributes and how available genetic material could help to satisfy those needs.
\end{abstract}

Keywords: Bactris gasipaes, Colombia, consumer preferences, genetic improvement, plant genetic resources, landraces. 


\section{Resumen}

Introducción. Los esfuerzos de mejoramiento genético de largo plazo, orientados a mejorar las capacidades técnicas y medios de subsistencia de productores de chontaduro (pejibaye) en América Latina, han demostrado ser ineficaces. Aunque los expertos coinciden en atribuir esto, parcialmente, a la gran incertidumbre que existe alrededor de las preferencias de los consumidores finales, dicha investigación es aun prácticamente inexistente. Objetivo. Identificar atributos químicos y morfológicos que son atractivos para consumidores finales de chontaduro, y cómo esos atributos se relacionan con percepciones finales de calidad del fruto, por medio de métodos estadísticos y econométricos. Materiales y métodos. Con base en la cosecha de un amplio conjunto de variedades de un banco de germoplasma de chontaduro (Bactris gasipaes) en el Suroeste de Colombia, 482 evaluaciones fueron hechas entre abril y octubre de 2016 por consumidores locales, quienes probaron los frutos y dieron un reporte sobre su percepción de sabor/calidad, en un esquema de estudio de caso. Combinando estos datos con información adicional sobre color de los frutos, percepción de oleaginosidad, y controles adicionales, se definió un modelo de regresión logit ordenado para identificar los atributos que describen los frutos de chontaduro con los puntajes más favorables por su percepción de sabor/calidad. Resultados. Las preferencias sobre contenido de aceite no fueron lineales. Frutos percibidos como altos en aceite tuvieron entre un 9 y $13 \%$ más de probabilidad de ser considerados como del mejor sabor/calidad, mientras aquellos que se percibieron como altos en almidón se correlacionan con una elevada aversión hacia el fruto, teniendo estos una reducción de $43 \%$ de probabilidad de ser identificados como entre los mejores frutos. Conclusión. Hay una gran cantidad de investigación aún pendiente alrededor de las preferencias de los consumidores de chontaduro y, además, esta debe de ser llevada a cabo de manera interdisciplinaria. Estudios de atributos deseables en chontaduro deben hacerse a escalas subnacionales, para identificar patrones aceptables de oleaginosidad y morfología, así como material genético disponible para satisfacer dicha meta.

Palabras clave: Bactris gasipaes, Colombia, preferencias de los consumidores, mejoramiento genético, recursos genéticos vegetales, razas nativas.

\section{Introduction}

The use of peach-palm (Bactris gasipaes) has long been part of Colombian culture (Patiño, 1992). Its fruit is of both dietary and economic relevance, and dates to pre-Colombian tribes in the Pacific and Western Amazon regions, as well as for most colonial and post-colonial groups that settled in those regions. Nowadays, in a context of globalization, the market for peach-palm fruit has rather declined, endangering the means of income and livelihoods of farmers who depend on its production (Clement et al., 2004). Research and development (R\&D) efforts have shown no significant effects in changing that trend. Some experts suggest that such ineffectiveness results from the sole focus that research has given to increased-production technologies, whilst a necessary body of research to assess consumers' preferences, means to connect farmers to markets, and the development of innovative markets for fruits and their derivates, remains virtually unexplored (Graefe et al., 2013).

Most peach-palm fruit farmers are located on marginal areas and are usually distributed across a wide range of agro-ecological conditions, while also facing different socioeconomic conditions from one place to another (Almekinders \& Elings, 2001). This implies a complex set of stresses (climatic, environmental and market-related), and risks (production, poverty) that need to be addressed through research. In this sense, a traditional genetic improvement program - which aims for a more uniform final production and production techniques - may not properly respond to peach-palm farmers' needs.

Evidence clearly indicates how peach-palm has not only a potential for human nutrition from direct consumption of fruits (Restrepo \& Estupiñán, 2007), but also due to its advantages for animal nutrition (Arroyo \& Murillo, 2000), 
transformation for food industry (Aguiar et al., 2019; Da Costa et al., 2019; Ferrari et al., 2020; Martínez-Girón et al., 2017; Pires et al., 2019), and even from the suitability of its stem fibers for improving construction materials (Vargas, 2015). This raises questions on why, apparently, this knowledge has not properly translated into a progressive refinement of genetic improvement programs that deliver relevant social impacts both on farmers and markets.

Crop improvement research that aims to achieve efficient responses to a high variety of stresses through the selection of promissory materials, demands large genetic variability (Cornelius et al., 2006). Most improvements for permanent crops follow conventional methods, and the selection of promissory materials based on agronomic and morphological traits (i.e. yield and quality) is particularly difficult for peach-palm, since those traits are polygenic and susceptible to environmental conditions. Furthermore, the selection of elite materials is feasible only after productive age has been reached, hence the production of improved genetic material demands a lot of time and resources (Adin et al., 2004; Clement, 2001; Clement \& Mora-Urpí, 1987; Mora-Urpí et al., 1997), since productive ages may vary between three and five years with thorough management, and even longer when is not the case.

Conventional methods for genetic improvement of peach-palm highly depend on the selection of superior individuals whose traits would hopefully be inherited by their progeny, so the cornerstone for its successful improvement are conditional to efficient estimation of genetic parameters. Yet the derived progenies from this process tend to be highly diverse and do not necessarily inherit their mother-traits. Therefore, asexual propagation (in vitro or cloning) might be a preferred strategy for mass production of promissory varieties (Flores et al., 2012; Graner, et al., 2020; Tracz et al., 2009). However, if these methods are to be used, breeders should do their best to avoid a scenario in which too few materials are propagated, since this would imply an increase on risks of impacts from pests and diseases on large scales. This has been clearly detected in other palm crops as banana in global scales, due to Fusarium oxysporum f. sp. cubense (Foc) back in the 1950's and within the last decade (Butler, 2013; Dita et al., 2018).

After more than forty years of R\&D efforts have been put for strengthening peach-palm fruit farmers in countries such as Brazil, Colombia, Costa Rica, and Peru, the results are discouraging. Beside a steadily decreasing production, only $40 \%$ of overall production is estimated to be commercialized, with only a fraction of it actually meeting final consumers' demands for quality (Clement et al., 2004). In addition, most funds for the peach-palm fruit research agenda were spent in establishing and maintaining large germplasm banks which were expensive to maintain and provided little practical results (Clement et al., 2004), making it unsustainable to pursue long-term programs.

Without evidence of - or paths on-sight for-strong impacts, research funding for the crop decreased and many collections disappeared (Ríos-Reyes et al., 2016; van Leeuwen et al., 2005). New strategies need to be devised if research on peach-palm aims to be maintained. A study was explored a new approach of participatory improvement program in Peru which proved helpful for both the reduction of fixed costs of maintaining large germplasm banks, and the expansion of the available genetic diversity that farmers can count on (Cornelius et al., 2006). Similar results were obtained in the Brazilian Amazon, following a similar approach (Van Leeuwen, 2009). If further analyses are placed on such strategies, it is possible to devise additional country-and region-specific mechanisms to make it more feasible to maintain the needed genetic diversity for an improvement program at lower costs.

Still, little is known about consumers' perceptions and preferences beside that most fruits do not achieve the consumers' expected traits of quality (Cornelius et al., 2006). Poll data suggest that consumers reportedly prefer medium-sized red fruits with moderate oil contents over others, both in Colombia and Brazil (Clement et al., 2004; Clement \& Santos, 2002; Graefe et al., 2013). Nonetheless, poll data were preferences on attributes are asked straightforwardly may include biases from non-representative sampling and, more important, from social constructions that do not necessarily nor fully reflect preferences based on sensory perceptions, that can be helpful for the refinement of genetic improvement programs.

A study aiming to properly determine what attributes are preferred and how their changes may affect the consumers' perceptions of quality/taste, should follow a sensory design on a large sample of fruits from which attributes are known. On such designs, consumers would be provided with fruits to taste and report their perceptions 
about them. The consumer acceptance for a peach-palm snack (chips) and the chemical traits of chips that related to such acceptance were analized by López-Calvo et al. (2015). But, to the knowledge of this study, there are no analyses of such kind for unprocessed peach-palm fruits that provide insights for genetic improvement. This paper, even though it does not strictly undertake a sensory design, aims to be a first step into filling that gap. Detailed information on how consumer quality perception of peach-palm fruits changes due to morphological or chemical traits (e.g. color and/or oil content, respectively) - it is derive from the present study regression analysis - , should prove useful to help build market-oriented research, that increases the odds that final production is more likely to be commercialized and accepted by final consumers. To pursue such end, this document identifies chemical and morphologic attributes that are attractive for final consumers of peach-palm fruit and how such attributes correlate with final perceptions of fruit quality, by means of statistical and econometric methods.

\section{Materials and methods}

Bias in the selection of promissory materials that follow poll-stated preferences is most likely to arise, due to the lack of information on how each interviewee experiences with peach-palm fruits were constructed. Specifically, there is no control on what was being tasted, therefore no real way to relate a preference to a specific genetic material. Between April and October of 2016, using samples from the peach-palm germplasm bank of the Colombian Corporation of Agricultural Research (AGROSAVIA) at the El Mira Research Center (Tumaco, Nariño, Colombia), 482 evaluations were made with individuals from Tumaco who were asked to choose fruits of their preference from a recent harvest, for them to taste and evaluate. The bank preserves materials (accessions) that come from six different Colombian departments (provinces), as well as from an experts'-selected group which is thought to be superior for either yield, fruit quality, or higher expected marketability (Table 1). Since previous poll data suggested that consumers prefer red fruits, the predominant color of the assigned fruits is registered on-delivery.

Peach-palm fruits are only edible after being boiled. For this study, consumers were responsible for cooking them. This approach could lead to unobserved factors that may influence the analysis, namely specific cultural cooking practices that may affect the perception of peach-palm fruits taste/quality. Nonetheless, since the sample is relatively large, that such disturbances are assumed to be purely random with no reason to expect that they would affect any specific perception for any specific group of fruits.

Consumers were asked to fill a report card that stated: (a) required time for cooking the fruits - in minutes-, (b) means of cooking - type of stove-, (c) whether the fruit was perceived as oily, (d) whether the fruit was perceived as moist, (e) whether the fruit was perceived as soft before cooking it, (f) sex of the respondent, and (f) a 1-to-5 scaled score given to the fruits based on their perceived taste/quality, where the scale was 1 if very bad, 2 if bad, 3 if neither good or bad, 4 if good, and 5 if very good.

The fruits evaluated were native to departments in the Colombian Pacific (Cauca, Nariño), and the department of Risaralda (in the Coffee Belt at the Andean Region)-Western races-, and Amazon (Guaviare, Caquetá, Putumayo) regions-Eastern races. Also, a group of specially selected (experts' choice) accessions available at the germplasm bank were evaluated. The latter were considered by experts to be superior for either yield, fruit quality, or higher expected marketability. Even though there was no traceability for the geographic source of this accessions, they were analyzed as a separate group to test whether they yielded results of perceived quality over the average.

The decision to include a question regarding perception moisture - different from oiliness - followed results from Leterme et al. (2005) that found a negative and significant relation between oil and starch contents in peachpalm fruits. A moist fruit is most likely a starchy one, since the starch gelatinizes from the fruits being boiled. The role of means-of-cooking variables were twofold: (a) it did not only account for the opportunity costs of using 
Table 1. List of peach-palm (Bactris gasipaes) accessions from where fruits were collected for perception analysis. El Mira Research Center. Tumaco, Nariño, Colombia. 2016.

Cuadro 1. Listado de accesiones de chontaduro (Bactris gasipaes), de las cuales se colectaron frutos para análisis de percepción. Centro de Investigación El Mira. Tumaco, Nariño, Colombia. 2016.

\begin{tabular}{lll}
\hline Department & Municipality & Accessions \\
\hline Cauca & Rosas & CA-001, CA-005, CA-006. \\
Caquetá & Florencia & CQ-009, CQ-028, CQ-032, CQ-034, CQ-036, CQ-042, CQ-060. \\
& Belén de los Andaquíes & CU-001. \\
& Currillo & CU-002, CU-004, CU-007, CU-011, CU-012, CU-013. \\
& La Montañita & MO-003. \\
& Albania & AL-001. \\
Guaviare & San José del Guaviare & GU-001, GU-003, GU-004, GU-005, GU-007, GU-009, GU-013, GU-014, GU-015, GU-017, \\
& & GU-018, GU-021, GU-022, GU-023, GU-031, GU-032, GU-033, GU-035, GU-036, GU-037, \\
& & GU-039, GU-042, GU-044, GU-046, GU-047. \\
& El Retorno & GU-025, GU-026, GU-027, GU-028. \\
& Puerto Concordia & GU-041. \\
Nariño & Calamar & GU-049, GU-050. \\
& Tumaco & TU-0005, TU-0010, TU-0011, TU-0012, TU-0013, TU-0014, TU-0016, TU-0019, TU-0020, \\
& & TU-0023, TU-0024, TU-0030, TU-0033, TU-0036, TU-0044, TU-0045, TU-0050, Unbranded \\
Putumayo & Orito & OR-039. \\
& Puerto Asís & PA-001, PA-017, PA-060. \\
& San Miguel & SM-053, SM-055, SM-056, SM-058. \\
& Villa Garzón & VG-005, VG-011, VG-013, VG-024, VG-030, VG-031, VG-032, VG-043, VG-044, VG-051. \\
Risaralda & Pueblo Rico & RI-0302, RI-0901, RI-1401, RI-1501, RI-1703, RI-1809, RI-2706, Unbranded special \\
& & selections (3). \\
\hline
\end{tabular}

Source: Elaborated by authors based on El Mira peach-palm fruit germplasm bank internal control data, 2016 / Fuente: Elaborado por los autores basados en datos de control interno del banco de germoplasma de chontaduro (pejibaye) de El Mira, 2016.

different means of cooking, but also (b) reflected a priori spatial and economic variability, even though individuals were located on a remote region of Colombia. These follow that an electrical stove requires either a stable grid connection or availability of a power generator, and that a natural-gas stove means either access to roads (for liquefied petroleum gas) or to a stable gas pipeline.

For the formal analysis, an ordered logit regression model (Cameron \& Trivedi, 2005; Long \& Freese, 2014) states that, for every individual, exists a latent variable $y_{i}^{*}$ that describes the perception of taste/quality of the tasted peach-palm fruit, that generally follows

$$
y_{i}^{*}=x_{i}^{\prime} \boldsymbol{\theta}+\varepsilon_{i}=\sum_{k=1}^{K} \theta_{k} x_{i k}+\varepsilon_{i},
$$

where $x_{i}$ is a vector of $\mathrm{K}$ attributes that affect the measure of taste/quality by their respective proportions in $\theta$, and $\varepsilon_{i}$ is an independently and identically distributed (i.i.d.) random shock. More detailly, $\boldsymbol{y}_{i}^{*}$ and $\boldsymbol{x}_{i}^{\prime} \boldsymbol{\theta}$ are set to follow:

$$
\begin{gathered}
y_{i}^{*}=\beta_{1} \text { Oily }_{i}+\beta_{2} \text { Moist }_{i}+\gamma \text { Soft }_{i}+\delta_{1} \text { Orange }_{i}+\delta_{2} \text { Red }_{i}+\delta_{3} \text { Yellow }_{i}+\zeta \text { Female }_{i} \\
+\eta \text { CookTime }_{i}+\lambda_{1} \text { Electric }_{i}+\lambda_{2} \text { Charcoal }_{i}+\varepsilon_{i} .
\end{gathered}
$$


Base categories for color (yellow-green) and means of cooking (natural-gas/LPG) are excluded from (1)' to avoid collinearity in regression analysis. Notice that the perception of oiliness and moistness were not assumed to be mutually exclusive, so that there is more flexibility and allowing for cases where respondents could report if the fruit was perceived as only oily, only moist, both, or neither.

Although $y_{i}^{*}$ is not directly observable, increasing thresholds $(\tau)$ that help determine whether the consumer consider the fruit to be very bad, bad, neither good or bad, good, or very good, are assumed to exist. Since $x_{i}$ is observed, there is also information about the unobserved preferences through the score variable, $y_{i}$, which satisfies

$$
\text { Score }_{i}=\left\{\begin{array}{ccc}
1 & \text { if } & y_{i}^{*} \leq \tau_{1} \\
2 & \text { if } & \tau_{1}<y_{i}^{*} \leq \tau_{2} \\
3 & \text { if } & \tau_{2}<y_{i}^{*} \leq \tau_{3} \\
4 & \text { if } & \tau_{3}<y_{i}^{*} \leq \tau_{4} \\
5 & \text { if } & \tau_{4}<y_{i}^{*} .
\end{array}\right.
$$

The paper then explores the determinants of the probability that an individual $i$ would give a specific score $j$ to the peach-palm fruits that he/she tasted, namely:

$$
\begin{aligned}
\operatorname{Pr}\left(\text { Score }_{i}=j \mid \boldsymbol{x}_{i}\right) & =\operatorname{Pr}\left(\tau_{j-1}<y_{i}^{*} \leq \tau_{j} \mid \boldsymbol{x}_{i}\right) \\
& =\operatorname{Pr}\left(\tau_{j-1}<\boldsymbol{x}_{i}^{\prime} \boldsymbol{\theta}+\varepsilon_{i} \leq \tau_{j}\right) \\
& =\operatorname{Pr}\left(\tau_{j-1}-\boldsymbol{x}_{i}^{\prime} \boldsymbol{\theta}<\varepsilon_{i} \leq \tau_{j}-\boldsymbol{x}_{i}^{\prime} \boldsymbol{\theta}\right) \\
& =\operatorname{Pr}\left(\tau_{j}-\boldsymbol{x}_{i}^{\prime} \boldsymbol{\theta}\right)-\operatorname{Pr}\left(\tau_{j-1}-\boldsymbol{x}_{i}^{\prime} \boldsymbol{\theta}\right) \\
& =F\left(\tau_{j}-\boldsymbol{x}_{i}^{\prime} \boldsymbol{\theta}\right)-F\left(\tau_{j-1}-\boldsymbol{x}_{i}^{\prime} \boldsymbol{\theta}\right),
\end{aligned}
$$

With $\mathrm{F}$ the cumulative distribution function of $\varepsilon_{i}$ and, in this case, $\tau_{0}=-\infty$ and $\tau_{5}=\infty$ by definition. Setting $F$ to be logistic, estimation of $\theta$ and $\tau_{j}$ is done by maximum likelihood (Cameron \& Trivedi, 2005; Cameron \& Trivedi, 2009; Greene, 2012; Long \& Freese, 2014). For a consistent model, it is necessary for thresholds to be statistically different (i.e. non-overlapping confidence intervals); otherwise, categories should be redefined, so this is tested in the document.

Finally, a focus was put on the analysis of the marginal effects of explanatory variables over the probability, namely:

$$
\frac{\partial \operatorname{Pr}\left(\text { Score }_{i}=j\right)}{\partial x_{i k}}=\left[f\left(\tau_{j-1}-\boldsymbol{x}_{i}^{\prime} \boldsymbol{\theta}\right)-f\left(\tau_{j}-\boldsymbol{x}_{i}^{\prime} \boldsymbol{\theta}\right)\right] \theta_{k},
$$

Where $f$ describes the probability density function associated to $F$, specially for scores $j=4$ and $j=5$, since it is important to identify what peach-palm fruit attributes have larger correlations with the probability to achieve a better perception among consumers (good or very good).

\section{Results}

Reported scores (Figure 1) show a distribution where less than $49 \%$ of the fruits where considered of good taste/quality (scores 4-5), and that there might be enough observations within each category to consider an ordered response regression model approach to analyze the patterns of preferences and their relationship with perceived fruit attributes. 


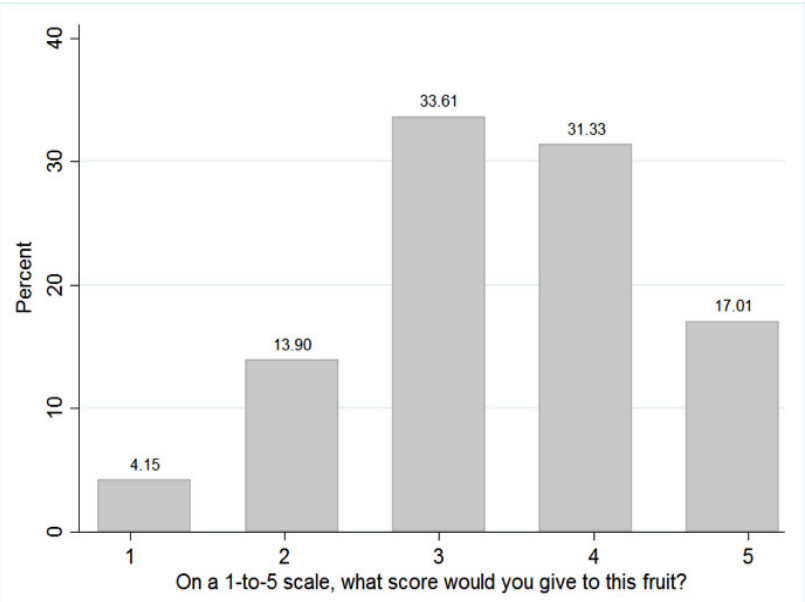

Figure 1. Percentage histogram of Taste/Quality Score given to peach-palm fruits (Bactris gasipaes) evaluated by consumers in Tumaco, Nariño, Colombia. 2016.

Figura 1. Histograma por porcentajes de puntuación de sabor/calidad dada a frutos de chontaduro (Bactris gasipaes) evaluados por consumidores en Tumaco, Nariño, Colombia. 2016.

The data used for the regression analysis is reported in Table 2. An approximate of 78 minutes were required on average to cook the fruits according to consumers, although this variable was only available for 430 observations. Despite its high variance, the reported cooking time was of interest for the model since it reflects opportunity costs of time. Also, nearly two thirds of respondents report to had cooked the fruits on a natural-gas stove/range, while only $16 \%$ made use of an electric stove, and the rest reported to had cooked on a wood/charcoal stove.

Nearly half of the assessments were done for yellow-green peach-palm fruits, and less than $7 \%$ of them were orange ones. The rest of the assessments were equivalently distributed between cases of red and yellow fruits. Including this variable was of great importance, since it would help to test whether a color may influence the perception of taste/quality either positively or negatively.

Coefficients reported on Table 3 are the estimates of $\theta$ defined on equation (1) and (1)' providing information about expected relations between peach-palm fruit attributes and average scoring. Results suggest that there was a positive relation of taste/quality scores with perception of oiliness on fruits, while a negative one arises for the perception of moisture (high levels of starch). Having yellow-green fruits as a base category, it was found that there is a higher chance to obtain better scores when the fruit is yellow.

Although, only 409 observations can be used when including information on means for cooking the fruits and cooking time, coefficients did not vary much when running the regressions only over that subsample. Moreover, fixed effects for source of the accessions creates little variation on the estimated coefficients, and not hold any statistical significance (not reported). The latter has two direct implications. First, when consumers are unaware of were an accession comes from, their perceptions of taste/quality may as well solely rely on visual and/or chemical attributes. And second, it could also be the case that experts' choices about superior materials, on their own, may not be enough to effectively carry a genetic improvement program that properly targets consumption markets.

Before advancing to the analysis of marginal effects, consistency of threshold estimates was checked, as summarized on Table 4 . Based on a $5 \%$ significance rule, the confidence intervals for each of the four calculated $\tau$ coefficients did not overlap; therefore, a five-categories analysis was statistically adequate to analyze the patterns of preferences and their relationship with attributes of interest. Notice that this holds for all four specifications that were presented in Table 3. 
Table 2. Descriptive statistics of variables used for ordered logit regression analysis. El Mira Research Center. Tumaco, Nariño, Colombia, 2016.

Cuadro 2. Estadísticas descriptivas de variables usadas para análisis de regresión logit ordenada. Centro de Investigación El Mira. Tumaco, Nariño, Colombia, 2016.

\begin{tabular}{|c|c|c|c|}
\hline Variable & $\begin{array}{l}(1) \\
\mathbf{N}\end{array}$ & $\begin{array}{l}\text { (2) } \\
\text { Mean / percentage }\end{array}$ & $\begin{array}{l}(3) \\
\text { S.D. }\end{array}$ \\
\hline On a 1-to-5 scale, what score would you give to this fruit? & 482 & 3.43 & 1.06 \\
\hline Required cooking time (minutes reported) & 430 & 77.99 & 27.99 \\
\hline Cooked on a natural gas/LPG stove/range & 482 & $64.30 \%$ & 0.48 \\
\hline Cooked on an electrical stove & 482 & $16.00 \%$ & 0.37 \\
\hline Cooked on a wood/charcoal stove & 482 & $19.70 \%$ & 0.40 \\
\hline Did you perceive the fruit as oily? $(1=$ Yes $)$ & 482 & $22.40 \%$ & 0.42 \\
\hline Did you perceive the fruit as moist? $(1=$ Yes $)$ & 482 & $10.80 \%$ & 0.31 \\
\hline Did you perceive the fruit as soft before cooking it? $(1=$ Yes $)$ & 482 & $6.64 \%$ & 0.25 \\
\hline Sex of respondent $(1=$ Female $)$ & 477 & $24.10 \%$ & 0.43 \\
\hline Predominantly orange fruits & 466 & $6.87 \%$ & 0.25 \\
\hline Predominantly red fruits & 466 & $26.20 \%$ & 0.44 \\
\hline Predominantly yellow fruits & 466 & $22.30 \%$ & 0.42 \\
\hline Predominantly yellow-green fruits & 466 & $44.60 \%$ & 0.50 \\
\hline Accession from Caquetá Department & 482 & $13.10 \%$ & 0.34 \\
\hline Accession from Cauca Department & 482 & $1.45 \%$ & 0.12 \\
\hline Accession from Guaviare Department & 482 & $48.10 \%$ & 0.50 \\
\hline Accession from Nariño Department & 482 & $5.60 \%$ & 0.23 \\
\hline Accession from Putumayo Department & 482 & $21.00 \%$ & 0.41 \\
\hline Accession from Risaralda Department & 482 & $2.07 \%$ & 0.14 \\
\hline Specially selected accession & 482 & $8.71 \%$ & 0.28 \\
\hline
\end{tabular}

Source: Elaborated by authors based on survey data / Fuente: Elaborado por los autores a partir de información de encuesta.

Marginal effects suggest that peach-palm fruits that were perceived as high in oil, were between 9 and $13 \%$ more likely to obtain the highest scores for taste/quality (Tables 5 and 6). On the other hand, fruits that were perceived as moist (high starch), were between 29 and $43 \%$ less likely to achieve the highest scores. These results suggest that consumers' preferences regarding peach-palm fruit oil contents were nonlinear. Therefore, additional gain on market success may be achieved by producing and marketing more succulent fruits, contrary to previous poll data that simply pointed to medium-oil fruits as preferred. Also, this would also suggest that a pre-selection process of promissory germplasm for fruit-markets should more rapidly identify and discard starchy fruits since these, apparently, create the most rejection among consumers.

Despite previous findings based on poll data suggested red fruits were preferred by consumers, yellow fruits were more likely to receive higher scores as compared to the base category (yellow-green fruits) within the 
Table 3. Ordered logit regression results for perceived quality of peach-palm fruits (Bactris gasipaes). El Mira Research Center. Tumaco, Nariño, Colombia, 2016.

Cuadro 3. Resultados de regresión logit ordenada sobre la percepción de calidad de frutos de chontaduro (Bactris gasipaes). Centro de Investigación El Mira. Tumaco, Nariño, Colombia, 2016.

\begin{tabular}{|c|c|c|c|c|}
\hline & (1) & $(2)$ & (3) & (4) \\
\hline Variables & $\operatorname{Pr}\left(y_{i}=j\right)$ & $\operatorname{Pr}\left(y_{i}=j\right)$ & $\operatorname{Pr}\left(y_{i}=j\right)$ & $\operatorname{Pr}\left(y_{i}=j\right)$ \\
\hline \multirow[t]{2}{*}{ Did you perceive the fruit as oily? } & $1.03 * * *$ & $1.07 * * *$ & $1.05 * * *$ & $1.07 * * *$ \\
\hline & $(0.21)$ & $(0.22)$ & $(0.23)$ & $(0.23)$ \\
\hline \multirow[t]{2}{*}{ Did you perceive the fruit as moist? } & $-3.48 * * *$ & $-3.50 * * *$ & $-3.49 * * *$ & $-3.52 * * *$ \\
\hline & $(0.40)$ & $(0.40)$ & $(0.44)$ & $(0.44)$ \\
\hline \multirow[t]{2}{*}{ Did you perceive the fruit as soft before cooking it? } & -0.18 & -0.18 & -0.19 & -0.19 \\
\hline & $(0.37)$ & $(0.37)$ & $(0.44)$ & $(0.45)$ \\
\hline \multirow[t]{2}{*}{ Predominantly orange fruits } & 0.00 & 0.03 & 0.31 & 0.36 \\
\hline & $(0.31)$ & $(0.31)$ & $(0.31)$ & $(0.31)$ \\
\hline \multirow[t]{2}{*}{ Predominantly red fruits } & -0.34 & -0.33 & -0.23 & -0.23 \\
\hline & $(0.21)$ & $(0.22)$ & $(0.23)$ & $(0.24)$ \\
\hline \multirow[t]{2}{*}{ Predominantly yellow fruits } & $0.48 * *$ & $0.48 * *$ & $0.62 * *$ & $0.60 * *$ \\
\hline & $(0.24)$ & $(0.24)$ & $(0.26)$ & $(0.26)$ \\
\hline \multirow[t]{2}{*}{ Sex of respondent $(1=$ Female $)$} & -0.28 & -0.26 & $-0.35^{*}$ & -0.33 \\
\hline & $(0.20)$ & $(0.20)$ & $(0.21)$ & $(0.22)$ \\
\hline \multirow[t]{2}{*}{ Required cooking time (minutes reported) } & & & 0.00 & 0.01 \\
\hline & & & $(0.00)$ & $(0.00)$ \\
\hline \multirow[t]{2}{*}{ Cooked on an electrical stove } & & & 0.22 & 0.23 \\
\hline & & & $(0.24)$ & $(0.25)$ \\
\hline \multirow[t]{2}{*}{ Cooked on a wood/charcoal stove } & & & 0.01 & -0.01 \\
\hline & & & $(0.23)$ & $(0.24)$ \\
\hline \multirow[t]{2}{*}{$\tau_{1}$} & $-4.28 * * *$ & $-4.37 * * *$ & $-3.74 * * *$ & $-3.78 * * *$ \\
\hline & $(0.35)$ & $(0.35)$ & $(0.45)$ & $(0.45)$ \\
\hline \multirow[t]{2}{*}{$\tau_{2}$} & $-2.01 * * *$ & $-2.09 * * *$ & $-1.60 * * *$ & $-1.63 * * *$ \\
\hline & $(0.20)$ & $(0.21)$ & $(0.34)$ & $(0.34)$ \\
\hline \multirow[t]{2}{*}{$\tau_{3}$} & 0.03 & -0.04 & 0.43 & 0.42 \\
\hline & $(0.16)$ & $(0.18)$ & $(0.33)$ & $(0.34)$ \\
\hline \multirow[t]{2}{*}{$\tau_{4}$} & $1.80 * * *$ & $1.73 * * *$ & $2.33 * * *$ & $2.33 * * *$ \\
\hline & $(0.18)$ & $(0.20)$ & $(0.35)$ & $(0.36)$ \\
\hline Observations $^{(a)}$ & 461 & 461 & 409 & 409 \\
\hline Accession Origin Fixed Effects & No & Yes & No & Yes \\
\hline Method & ML & ML & ML & ML \\
\hline
\end{tabular}

(a) A reduced number of observations is used for regression analysis since there were missing values for some variables (recall Table 2) across observations. Only observations with the full set of data are suitable for modeling / a) Un número reducido de observaciones fue usado para el análisis de regresión, por cuanto existen datos no observados para algunas variables (ver Cuadro 2) en algunas de las observaciones. Únicamente observaciones con el total de variables fueron apropiados para la modelación.

Robust standard errors in parentheses. P-values: ${ }^{* * *} \mathrm{p}<0.01,{ }^{*} \mathrm{p}<0.05,{ }^{*} \mathrm{p}<0.1$ / Errores estándares robustos en paréntesis. P-valores: $* * * \mathrm{p}<0,01, * * \mathrm{p}<0,05, * \mathrm{p}<0,1$. 
Table 4. Threshold estimates' confidence intervals in ordered logit regression analysis for the perceived quality of peach-palm fruits (Bactris gasipaes). El Mira Research Center. Tumaco, Nariño, Colombia. 2016.

Cuadro 4. Estimación de intervalos de confianza para puntos de corte en regresión logit ordenada para la calidad percibida en frutos de chontaduro (Bactris gasipaes), Centro de Investigación El Mira. Tumaco, Nariño, Colombia. 2016.

\begin{tabular}{cccc}
\hline \multirow{2}{*}{ Threshold } & \multicolumn{3}{c}{ Case (1) } \\
\cline { 2 - 4 } & Coefficient Estimate & Lower Bound & Upper Bound \\
\hline$\tau_{1}$ & -4.28 & -4.96 & -3.59 \\
$\tau_{2}$ & -2.01 & -2.40 & -1.61 \\
$\tau_{3}$ & 0.03 & -0.28 & 0.34 \\
$\tau_{4}$ & 1.80 & 1.44 & 2.16 \\
\hline$\tau_{1}$ & & Case (2) & -3.69 \\
$\tau_{2}$ & -4.37 & -5.05 & -1.68 \\
$\tau_{3}$ & -2.09 & -2.50 & 0.30 \\
$\tau_{4}$ & -0.04 & -0.39 & 2.13 \\
\hline$\tau_{1}$ & 1.73 & 1.34 & -2.85 \\
$\tau_{2}$ & & Case (3) & -0.94 \\
$\tau_{3}$ & -3.74 & -4.63 & 1.07 \\
$\tau_{4}$ & -1.60 & -2.26 & 3.01 \\
\hline$\tau_{1}$ & 0.43 & -0.21 & -2.89 \\
$\tau_{2}$ & 2.33 & 1.65 & -0.96 \\
$\tau_{3}$ & -3.78 & Case (4) & 1.09 \\
$\tau_{4}$ & -1.63 & -4.66 & 3.04 \\
\hline
\end{tabular}

Confidence intervals with a 95\% level of confidence / Intervalos de confianza con un nivel de 95\% de confianza.

study sample. Other fruits' colors showed no statistical differences with respect to the base category. One of two implications may derive from this: (a) it might not be a matter of whether peach-palm fruits were of one color or other, but it was actually a matter of taste/quality which, for the study, was the case of yellow fruits; or, (b) otherwise, it could be the case that preferences on visual attributes-color-may present large variations across different targeted markets. Unfortunately, the available data does not allow to test which should hold true.

It should also be noted that variables such as previous-to-cook perception of fruit softness, required time for cooking, and means for cooking, showed no apparent relation with achieved fruit scores, as it was also the case for female respondents in most specifications. Note that the results held also for marginal effects despite a loss of over fifty observations when including these latter variables. Finally, similar to overall correlations on Table 2, marginal effects did not show a great deal of change when controlling for fixed effects of geographical origin of the genetic material, which was unknown to consumers who provided the final scores for taste/quality. 
Table 5. Marginal effects for peach-palm fruits (Bactris gasipaes) with a quality score of 4, in different ordered logit regression specifications. El Mira Research Center. Tumaco, Nariño, Colombia. 2016.

Cuadro 5. Efectos marginales para frutos de chontaduro (Bactris gasipaes) con calificación de calidad 4, en diferentes especificaciones de regresión logit ordenada. Centro de Investigación El Mira. Tumaco, Nariño, Colombia. 2016.

\begin{tabular}{|c|c|c|c|c|}
\hline Variables & $\begin{array}{c}(1) \\
\Delta \operatorname{Pr}\left(y_{i}=4\right)\end{array}$ & $\begin{array}{c}(2) \\
\Delta \operatorname{Pr}\left(y_{i}=4\right)\end{array}$ & $\begin{array}{c}(3) \\
\Delta \operatorname{Pr}\left(y_{i}=4\right)\end{array}$ & $\begin{array}{c}(4) \\
\Delta \operatorname{Pr}\left(y_{i}=4\right)\end{array}$ \\
\hline Did you perceive the fruit as oily? & $\begin{array}{c}0.09 * * * \\
(0.02)\end{array}$ & $\begin{array}{c}0.09 * * * \\
(0.02)\end{array}$ & $\begin{array}{c}0.09 * * * \\
(0.02)\end{array}$ & $\begin{array}{c}0.09 * * * \\
(0.02)\end{array}$ \\
\hline Did you perceive the fruit as moist? & $\begin{array}{c}-0.30 * * * \\
(0.05)\end{array}$ & $\begin{array}{c}-0.30 * * * \\
(0.05)\end{array}$ & $\begin{array}{c}-0.30 * * * \\
(0.05)\end{array}$ & $\begin{array}{c}-0.29 * * * \\
(0.05)\end{array}$ \\
\hline Did you perceive the fruit as soft before cooking it? & $\begin{array}{l}-0.02 \\
(0.03)\end{array}$ & $\begin{array}{l}-0.02 \\
(0.03)\end{array}$ & $\begin{array}{l}-0.02 \\
(0.04)\end{array}$ & $\begin{array}{l}-0.02 \\
(0.04)\end{array}$ \\
\hline Predominantly orange fruits & $\begin{array}{c}0.00 \\
(0.03)\end{array}$ & $\begin{array}{c}0.00 \\
(0.03)\end{array}$ & $\begin{array}{c}0.03 \\
(0.03)\end{array}$ & $\begin{array}{c}0.03 \\
(0.03)\end{array}$ \\
\hline Predominantly red fruits & $\begin{array}{l}-0.03 \\
(0.02)\end{array}$ & $\begin{array}{l}-0.03 \\
(0.02)\end{array}$ & $\begin{array}{l}-0.02 \\
(0.02)\end{array}$ & $\begin{array}{l}-0.02 \\
(0.02)\end{array}$ \\
\hline Predominantly yellow fruits & $\begin{array}{c}0.04 * * \\
(0.02)\end{array}$ & $\begin{array}{l}0.04 * * \\
(0.02)\end{array}$ & $\begin{array}{c}0.05 * * \\
(0.02)\end{array}$ & $\begin{array}{l}0.05^{* *} \\
(0.02)\end{array}$ \\
\hline Sex of respondent $(1=$ Female $)$ & $\begin{array}{l}-0.02 \\
(0.02)\end{array}$ & $\begin{array}{l}-0.02 \\
(0.02)\end{array}$ & $\begin{array}{l}-0.03 * \\
(0.02)\end{array}$ & $\begin{array}{l}-0.03 \\
(0.02)\end{array}$ \\
\hline Required cooking time (minutes reported) & & & $\begin{array}{c}0.00 \\
(0.00)\end{array}$ & $\begin{array}{c}0.00 \\
(0.00)\end{array}$ \\
\hline Cooked on an electrical stove & & & $\begin{array}{c}0.02 \\
(0.02)\end{array}$ & $\begin{array}{c}0.02 \\
(0.02)\end{array}$ \\
\hline Cooked on a wood/charcoal stove & & & $\begin{array}{c}0.00 \\
(0.02)\end{array}$ & $\begin{array}{l}-0.00 \\
(0.02) \\
\end{array}$ \\
\hline Observations & 461 & 461 & 409 & 409 \\
\hline Accession Origin Fixed Effects & No & Yes & No & Yes \\
\hline Method & ML & ML & ML & ML \\
\hline
\end{tabular}

Robust standard errors in parentheses. P-values: *** $\mathrm{p}<0.01$, ** $\mathrm{p}<0.05$, $* \mathrm{p}<0.1$ / Errores estándar robustos en paréntesis. P-valores: $* * * \mathrm{p}<0,01, * * \mathrm{p}<0,05, * \mathrm{p}<0,1$.

\section{Discussion}

The previous results highlight the great deal of research yet to be done around peach-palm fruit consumer preferences and, furthermore, that it should be carried on an interdisciplinary ground. Even though this analysis is a first attempt to model consumer preferences, it is clear that more robust (i.e. laboratory based) measures of fruits' oil and/or starch contents would allow to first determine how accurate consumer's perceptions over these attributes really are, and then more precisely identify how overall preferences respond to such attributes. Moreover, complete 
Table 6. Marginal effects for peach-palm fruits (Bactris gasipaes) with a quality score of 5, in different ordered logit regression specifications. El Mira Research Center. Tumaco, Nariño, Colombia. 2016.

Cuadro 6. Efectos marginales para frutos de chontaduro (Bactris gasipaes) con calificación de calidad 5, en diferentes especificaciones de regresión logit ordenada. Centro de Investigación El Mira. Tumaco, Nariño, Colombia. 2016.

\begin{tabular}{|c|c|c|c|c|}
\hline \multirow{2}{*}{ Variables } & (1) & (2) & (3) & (4) \\
\hline & $\Delta \operatorname{Pr}\left(y_{i}=5\right)$ & $\Delta \operatorname{Pr}\left(y_{\mathrm{i}}=5\right)$ & $\Delta \operatorname{Pr}\left(y_{i}=5\right)$ & $\Delta \operatorname{Pr}\left(y_{\mathrm{i}}=5\right)$ \\
\hline \multirow[t]{2}{*}{ Did you perceive the fruit as oily? } & $0.13 * * *$ & $0.13 * * *$ & $0.13 * * *$ & $0.13 * * *$ \\
\hline & $(0.03)$ & $(0.03)$ & $(0.03)$ & $(0.03)$ \\
\hline \multirow[t]{2}{*}{ Did you perceive the fruit as moist? } & $-0.44 * * *$ & $-0.44 * * *$ & $-0.43 * * *$ & $-0.43 * * *$ \\
\hline & $(0.06)$ & $(0.06)$ & $(0.06)$ & $(0.06)$ \\
\hline \multirow[t]{2}{*}{ Did you perceive the fruit as soft before cooking it? } & -0.02 & -0.02 & -0.02 & -0.02 \\
\hline & $(0.05)$ & $(0.05)$ & $(0.05)$ & $(0.06)$ \\
\hline \multirow[t]{2}{*}{ Predominantly orange fruits } & 0.00 & 0.00 & 0.04 & 0.04 \\
\hline & $(0.04)$ & $(0.04)$ & $(0.04)$ & $(0.04)$ \\
\hline \multirow[t]{2}{*}{ Predominantly red fruits } & -0.04 & -0.04 & -0.03 & -0.03 \\
\hline & $(0.03)$ & $(0.03)$ & $(0.03)$ & $(0.03)$ \\
\hline \multirow[t]{2}{*}{ Predominantly yellow fruits } & $0.06 * *$ & $0.06^{*}$ & $0.08 * *$ & $0.07 * *$ \\
\hline & $(0.03)$ & $(0.03)$ & $(0.03)$ & $(0.03)$ \\
\hline \multirow[t]{2}{*}{ Sex of respondent $(1=$ Female $)$} & -0.03 & -0.03 & -0.04 & -0.04 \\
\hline & $(0.03)$ & $(0.03)$ & $(0.03)$ & $(0.03)$ \\
\hline \multirow[t]{2}{*}{ Required cooking time (minutes reported) } & & & 0.00 & 0.00 \\
\hline & & & $(0.00)$ & $(0.00)$ \\
\hline \multirow[t]{2}{*}{ Cooked on an electrical stove } & & & 0.03 & 0.03 \\
\hline & & & $(0.03)$ & $(0.03)$ \\
\hline \multirow[t]{2}{*}{ Cooked on a wood/charcoal stove } & & & 0.00 & -0.00 \\
\hline & & & $(0.03)$ & $(0.03)$ \\
\hline Observations & 461 & 461 & 409 & 409 \\
\hline Accession Origin Fixed Effects & No & Yes & No & Yes \\
\hline Method & ML & ML & ML & ML \\
\hline
\end{tabular}

Robust standard errors in parentheses. P-values: $* * * \mathrm{p}<0.01, * * \mathrm{p}<0.05, * \mathrm{p}<0.1$ / Errores estándar robustos en paréntesis. P-valores: $* * * \mathrm{p}<0,01, * * \mathrm{p}<0,05, * \mathrm{p}<0,1$.

sensory evaluations that properly identify diversity among consumers and their preferences should take place before pursuing any R\&D efforts for peach-palm improvement. Previous attempts to develop peach-palm varieties appear to have mostly relied on anecdotical evidence-which might be biased (e.g. assuming red fruits are always preferred)-, whereas a final consumer preference-based approach remains virtually unexplored, hence ruling aside a potential mechanism to more efficiently target connecting farmers to markets.

Nonetheless, it is not only a matter of technicalities around proper quantitative research methods. Peach-palm is not only of importance due to the scientific efforts surrounding it, but also for its role in the livelihoods of farmers 
in marginal areas. If an expansion of the crop's market is desired, then more awareness should be achieved among consumers to expect it to maintain - at least on early stages - its rustic presentation and inhomogeneous fruits since, most likely, farmers will not be able to comply with such trait demands, which are common in a globalized market. Without such efforts, there will be no suitable way for peach-palm fruit farmers to progressively grow in technology adoption, and in better linking themselves with both markets and final consumers.

Evidence presented here suggest that there is a positive nonlinear relation between fruits' oil contents and perceived quality: despite there might be payout for a fruit when it is perceived as higher in oil that usual, there is a larger (in absolute value) negative relation in payout when a fruit is perceived as more moist (high in starch). Specifically, fruits perceived as oilier were between 9 and $13 \%$ more likely to receive the highest scores, whilst their high-starch counterparts were around $43 \%$ less likely to receive high scores (recall tables 5 and 6). Also, contrasting previous findings from poll data for Colombia and Brazil, yellow fruits were the ones to be perceived with a higher level of quality (on average) instead of red or orange ones, which clearly contrast with the results of Clement et al. (2004), Clement \& Santos (2002), and Graefe et al. (2013) for Colombia and Brazil, which are solely based on poll data, and reported that red, mid-sized and average-oil fruits were largely preferred over others.

The natural variability of chemical and morphological attributes of peach-palm fruits strongly relates to its differentiated use between human consumption - which extends to flours, bakery, preserves, oil, etc. - and animal targeted consumption, with high-oil and low-fiber fruits specially appreciated in the former (Clement \& Arkcoll, 1991; Clement \& Mora-Urpí, 1987; Carvalho et al., 2013; Ferreira \& Pena, 2003; Yuyama et al., 2003; Kerr et al., 1997). Therefore, characterizing genetic materials with economic potential, i.e. that produce fruits that are more appealing for consumption markets, is of the upmost importance (Carvalho et al., 2009). Consumer preferences are a factor of great importance at the moment of developing improved varieties. Yet again, complying with all of consumer's preferred attributes is a challenging task, as some of those attributes are negatively correlated among currently available materials.

Two factors further increase the difficulty of this task. First, peach-palm is a crop still in early domestication and presents a high phenotypic variability. This is particularly visible in the fruits, since a plant can display clusters of them that vary in size and taste, effect that responds to crossed pollination (Yuyama, 2005). And, second, it is currently difficult for consumers to find fruits of consistent and specific attributes since farmers usually rely on non-selected seeds when installing new plots for this crop. This directly affects the homogeneity of the product that is commercialized (Clement et al., 2004).

\section{Conclusion}

The results presented in this paper are of high importance to the future of research and development (R\&D) efforts on peach-palm in Colombia since they evidence how, if not addressed, the void in the literature about peachpalm consumers' preferences will endanger any research efforts, and consequently its farmers - whom are already in a position of high socioeconomic vulnerability. Further analyses of desired fruit traits should be made at intra-national levels, identifying ranges of suitable oiliness and morphological expected attributes and how available genetic material could help to satisfy those needs. Any future R\&D strategy should follow an interdisciplinary approach that better integrate genetic improvement and socioeconomic analysis, but that is not the only required change.

To make it feasible for farmers to remain in this crop and for markets to expand, a great deal of effort should be made to make consumers aware of how this traditional fruit-although rustic and inhomogeneous - remains as a good source of nutrition, and as a significant mean of income for rural families. The challenge ahead for ongoing and future genetic improvement programs around peach-palm lies on the proper identification of market niches 
that their products and sub-products should target, balancing genetic diversity and quality, hence safeguarding production and income sustainability.

\section{Disclaimer}

The authors agree with the publication of this article and declare that there are no conflicts of interest that affect the results.

\section{References}

Adin, A., Weber, J. C., Montes, C. S., Vidaurre, H., Vosman, B., \& Smulders, M. J. M. (2004). Genetic differentiation and trade among populations of peach palm (Bactris gasipaes Kunth) in the Peruvian Amazon - implications for genetic resource management. Theoretical and Applied Genetics, 108(8), 1564-1573. https://doi.org/10.1007/s00122-003-1581-9

Aguiar, J. P. L., Yuyama, K., \& Souza, F. D. C. D. A. (2019). Caracterização dos frutos de Pupunheira (Bactris gasipaes Kunth) cultivada na vila do Equador. Scientia Amazonia, 8(1), CA1-CA5.

Almekinders, C. J. M., \& Elings, A. (2001). Collaboration of farmers and breeders: Participatory crop improvement in perspective. Euphytica, 122, 425-38. https://doi.org/10.1023/A:1017968717875

Arroyo, C. L., \& Murillo, M. (2000). Utilización del pejibaye (Bactris gasipaes) en la alimentación animal. Nutrición Animal Tropical, 6(1), 145-68.

Butler, D. (2013). Fungus threatens top banana. Nature, 504(7479), 195-196. https://doi.org/10.1038/504195a

Cameron, A. C., \& Trivedi, P. K. (2005). Microeconometrics: Methods and Applications. Oxford University Press.

Cameron, A. C., \& Trivedi, P. K. (2009). Microeconometrics using Stata. The Stata Press.

Carvalho, A. V., Beckman, J. C., Maciel, R. A., \& Farias Neto, J. T. (2013). Características físicas e químicas de frutos de pupunheira no estado do Pará. Revista Brasileira de Fruticultura, 35(3), 763-768. https://doi.org/10.1590/S010029452013000300013

Carvalho, A. V., Vasconcelos, M. A. M., Silva, P. A., \& Ascheri, J. L. R. (2009). Produção de snacks de terceira geração por extrusão de misturas de farinhas de pupunha e mandioca. Brazilian Journal of Food Technology, 12(4), $277-284$. https:/doi.org/10.4260/BJFT200980090022

Clement, C. R. (2001). Melhoramento de espécies nativas [Improvement of native species]. In L. L. Nass (Ed.), Recursos genéticos \& melhoramento - plantas (pp. 423-441). Fundação de Apoio à Pesquisa Agropecuária de Mato Grosso.

Clement, C. R., \& Arkcoll D. B. (1991). The pejibaye (Bactris gasipaes H.B.K., Palmae) as an oil crop: potential and breeding strategy. Oleagineux, 46, 293-299.

Clement, C. R., \& Mora-Urpí, J. E. (1987). Pejibaye palm (Bactris gasipaes, Arecaceae): multi-use potential for the lowland humid tropics. Economic Botany, 41, 302-11. https://doi.org/10.1007/BF02858977

Clement, C. R., \& Santos, L. A. (2002). Pupunha no mercado de Manaus: preferências de consumidores e suas implicações. Revista Brasileira de Fruticultura, 24(3), 778-79. https://doi.org/10.1590/S0100-29452002000300055 
Clement, C. R., Weber, J. C., van Leeuwen, J., Astorga-Domian, C., Cole, D. M., Arévalo-López, L. A, \& Argüello, H. (2004). Why extensive research and development did not promote use of peach palm fruit in Latin America. Agroforestry Systems, 61, 195-206. https://doi.org/10.1023/B:AGFO.0000028999.84655.17

Cornelius, J. P., Clement, C. R., Weber, J. C., Sotelo-Montes, C., van Leeuwen, J., Ugarte-Guerra, L. J., Ricse-Tembladera, A., \& Arévalo-López, L. (2006). The trade-off between genetic gain and conservation in a participatory improvement programme: the case of peach-palm (Bactris gasipaes Kunth). Forests, Trees, and Livelihoods, 16, 17-34. https://doi. org/10.1080/14728028.2006.9752543

Da Costa, R. D. S., da Cruz Rodrigues, A. M., Laurindo, J. B., \& da Silva, L. H. M. (2019). Development of dehydrated products from peach palm-tucupi blends with edible film characteristics using refractive window. Journal of Food Science and Technology, 56(2), 560-570. https://doi.org/10.1007/s13197-018-3454-x

Dita, M., Barquero, M., Heck, D., Mizubuti, E. S. G., \& Staver, C. P. (2018). Fusarium wilt of banana: current knowledge on epidemiology and research needs toward sustainable disease management. Frontiers in Plant Science, 9, 1468. https:// doi.org/10.3389/fpls.2018.01468

Ferrari, M. H., Souza, M., Villas, F., Lopes, C., Landi, C. M., Michielon, S., Pedrosa, M. T., \& Côrtes, L. M. (2020). Characterization and technological properties of peach palm (Bactris gasipaes var. gasipaes) fruit starch. Food Research International, 136, 109569. https://doi.org/10.1016/j.foodres.2020.109569

Ferreira, C. D., \& Pena, R. S. (2003). Comportamento higroscópico da farinha de pupunheira. Ciência e Tecnologia de Alimentos, 23(2), 251-255. https://doi.org/10.1590/S0101-20612003000200025.

Flores, W. B., Yuyama, K., \& da Silva, R. G. (2012). Asexual propagation of peach palm by division of the clump and extraction of the off-shoots. Horticultura Brasileira, 30(1), 151-54. https://doi.org/10.1590/S0102-05362012000100025

Graefe, S., Dufour, D., van Zonneveld, M., Rodriguez, F., \& Gonzalez, A. (2013). Peach palm (Bactris gasipaes) in tropical Latin America: implications for biodiversity conservation, natural resource management and human nutrition. Biodiversity and Conservation, 22, 269-300. https://doi.org/10.1007/s10531-012-0402-3

Graner, É. M., Brondani, G. E., de Almeida, C. V., Batagin-Piotto, K. D., \& de Almeida, M. (2020). Decreased morphogenetic potential in peach palm stem-like cells in long-term in vitro conditions. Journal of Forestry Research, 31(2), 485-495. https://doi.org/10.1007/s11676-018-0769-4

Greene, W. H. (2012). Econometric Analysis (7th ed.). Prentice-Hall.

Kerr, L. S., Clement, R. N. S., Clement, C. R., \& Kerr, W. E. (1997). Cozinhando com a Pupunha. INPA.

Leterme, P., Garcia, M. F., Londoño, A. M., Rojas, M. G., Buldgen, A., \& Souffrant, W. B. (2005). Chemical composition and nutritive value of peach-palm (Bactris gasipaes Kunth) in rats. Journal of the Science of Food and Agriculture, 85(9), 1505-1512. https://doi.org/10.1002/jsfa.2146

Long, J. S., \& Freese, J. (2014). Regression Models for Categorical and Limited Dependent Variables with Stata (2nd ed.). Stata Press.

López-Calvo, R., Pérez, A. M., Ivankovich, C., Calderón, S., \& Pineda, M. L. (2015). Evaluación de la aceptación por consumidores de un bocadillo de pejibaye (Bactris gasipaes) y estudio de su potencial como alimento funcional. Archivos Latinoamericanos de Nutrición, 65(1), 51-58. 
Martínez-Girón, J., Rodríguez-Rodríguez, X., Pinzón-Zárate, L. X., \& Ordóñez-Santos, L. E. (2017). Caracterización fisicoquímica de harina de residuos del fruto de chontaduro (Bactris gasipaes Kunth, Arecaceae) obtenida por secado convectivo. Ciencia y Tecnología Agropecuaria, 18(3), 599-613. https://doi.org/10.21930/rcta.vol18_num3_art:747

Mora-Urpí, J. E., Weber, J., \& Clement, C. R. (1997). Peach palm (Bactris gasipaes Kunth). Promoting the Conservation and Use of Underutilized and Neglected Crops. International Plant Genetics Resources Institute.

Patiño, V. (1992). An ethnobotanical sketch of the palm Bactris (Guilielma) gasipaes. Principes, 36(3), $143-147$.

Pires, M. B., Amante, E. R., Lopes, A. S., Rodrigues, A. M. D. C., \& Silva, L. H. M. D. (2019). Peach palm flour (Bactris gasipaes Kunth): potential application in the food industry. Food Science and Technology, 39(3), 613-619.

Restrepo, J., \& Estupiñán, J. A. (2007). Potencial del chontaduro (Bactris gasipaes H.B.K.) como fuente alimenticia de alto valor nutricional en países tropicales. Revista de Ciencias, 11, 1-8. http://dx.doi.org/10.1590/fst.34617

Ríos-Reyes, L. D., Castillo-Hernández, E., \& Fuchs-Castillo, E. (2016). Estado actual del banco de germoplasma de pejibaye (Bactris gasipaes), Guápiles, Costa Rica. Agronomía Mesoamericana, 27(2), 311-317. http://dx.doi.org/10.15517/ am.v27i2.20737

Tracz, A. L. A., Wendling, I., Kalil Filho, A. N., dos Santos, Á. F., \& Quoirin, M. G. G. (2009). Enraizamento de perfilhos de pupunheira (Bactris gasipaes). Pesquisa Florestal Brasileira, 58, 69-75. https://doi.org/10.4336/2009.pfb.58.67

van Leeuwen, J. (2009). O melhoramento participativo de espécies agroflorestais: uma proposta para a pupunheira (Bactris gasipaes) para a produção de fruto. In R. Porro (Ed.), Alternativa agroflorestal na Amazônia em transformação (pp. 805-825). Embrapa Informação Tecnológica.

van Leeuwen, J., Lleras-Pérez, E., \& Clement, C. R. (2005). Field genebanks may impede instead of promote crop development: lessons of failed genebanks of "promising” Brazilian palms. Agrociencia, 9(1), 61-66.

Vargas, N. (2015). Caracterización físico-mecánica de las fibras de la palma de chontaduro. Revista INVENTUM, 10(19), 55-60. https://doi.org/10.26620/uniminuto.inventum.10.19.2015.53-58

Yuyama, K. (2005). Melhoramento de pupunheira para produção de palmito no INPA. Reunião Técnica do Projeto de PROBIO/ MMA Pupunha-raças primitivas e parentes silvestres. Recovered from: https://www.inpa.gov.br/pupunha/probio/ INPA_palmito.pdf

Yuyama, L. K. O., Aguiar, J. P. L., Yuyama, K., Clement, C. R., Macedo, S. H. M., Favaro, D. I. T., Afonso, C., Vasconcellos, M. B. A., Pimentel, S. A., Badolato, E. S. G., \& Vannuncchi, H. (2003). Chemical composition of the fruit mesocarp of three peach palm (Bactris gasipaes) populations grown in central Amazonia Brazil. International Journal of Food Science and Nutrition, 54(1), 49-56. https://doi.org/10.1080/096374803/000061994 